\title{
Satelite bidezko itsas gainazaleko tenperatura eta klorofila kontzentrazioen berreraikitzea. Azken hamarkadetako eta urtaroen zikloaren bilakaera Bizkaiko Golkoan
}

\author{
(Reconstruction of satellite Sea Surface Temperature \\ and Chlorophyll images. Evolution of values and seasonal cycle over \\ the last decades in the Bay of Biscay)
}

\author{
Ganix Esnaola*1,2, Jon Saenz $z^{2,3}$, Gabriel Ibarra-Berastegi $i^{2,3}$ \\ ${ }^{1}$ Ing. Nuklearra eta Jariakinen Mekanika, Euskal Herriko Unibertsitatea (UPV/EHU) \\ ${ }^{2}$ Joint Research Unit (UPV/EHU-IEO), Euskal Herriko Unibertsitatea (UPV/EHU) \\ ${ }^{3}$ Fisika Aplikatua II, Euskal Herriko Unibertsitatea (UPV/EHU)
}

LABURPENA: Satelite bidezko itsas gainazaleko tenperatura eta klorofila kontzentrazio irudiei lainoek eragindako zuloak betetzeko DINEOF teknika aplikatu zaie, zulorik gabeko eguneroko maiztasuneko hamarkadetako irudi sortak sortzeko asmoarekin. Irudi sorta horien azterketa egin da ondoren bi aldagaietan urtaroen zikloa aztertzeko, bai bere anplitudeari zein bere faseari dagokienez. Azterketak erakusten du tenperaturaren urtaro zikloaren anplitudeak $0,11^{\circ} \mathrm{C}$ /hamarkada balioko joera gorakor adierazgarria duela baina ez horrela klorofila kontzentrazioarenak. Faseari dagokionez, berriz, ez da joera adierazgarririk detektatu bi aldagaietako batean ere.

HITZ GAKOAK: satelite bidezko ozeanografia, itsas gainazaleko tenperatura, itsas gainazaleko klorofila kontzentrazioa, urtaroen zikloa, DINEOF, klima aldaketa.

ABSTRACT: Satellite sea surface temperate and chlorophyll concentration images have been processed using DINEOF technique to fill the gaps created by the presence of clouds in satellite images. This set of satellite temperature and chlorophyll images have then been used to analyse their respective seasonal cycles, both regarding the amplitude of the cycle and its phase. The results show a significant growing trend in the amplitude of the seasonal cycle with a value of $0.11^{\circ} \mathrm{C} /$ decade in the case of the temperature, but no significant trend for chlorophyll. Again, no significant trend is observed in the phase of the cycle in both variables.

KEYWORDS: satellite oceanography, sea surface temperature, sea surface chlorophyll concentration, seasonal cycle, DINEOF, climate change.

\footnotetext{
* Harremanetan jartzeko / Corresponding author: Ganix Esnaola, Ing. Nuklearra eta Jariakinen Mekanika, Euskal Herriko Unibertsitatea (UPV/EHU), Gipuzkoako Ingeniaritza Eskola-Donostia, Europa Plaza 1, 20018 Donostia. Euskal Herria. - ganix. esnaola@ehu.eus - https://orcid.org/0000-0001-9058-043X.

Nola aipatu / How to cite: Esnaola, Ganix; Saenz, Jon; Ibarra-Berastegi, Gabriel (2020). "Satelite bidezko itsas gainazaleko tenperatura eta klorofila kontzentrazioen berreraikitzea. Azken hamarkadetako eta urtaroen zikloaren bilakaera Bizkaiako Golkoan»; Ekaia, ale berezia 2020, 109-124. (https://doi.org/10.1387/ekaia.21046).
}

Jasoa: 27 uztaila, 2019; Onartua: 06 azaroa, 2019

ISSN 0214-9001 - elSSN 2444-3255 / (c) 2020 UPV/EHU

cc)(9) Obra hau Creative Commons Atribución 4.0 Internacional-en

Aizentziapean dago 


\section{SARRERA}

Itsas gainazaleko aldagai geofisiko eta biologikoez ari garenean paregabeko informazio iturria dira satelite bidezko behaketak. Tokian bertan, itsasoan, egindako neurketekin alderatuz gero estaldura espazial askoz handiagoa eskaintzen dute, eta oro har neurketa maitasun zein bereizmen espazial hobeak ere bai. Aipatu behar da abantaila horietaz gainera sateliteek itsasoaren gainazala soilik behatzen dutela, eta gainazalaz azpiko informazioa behar denean erabilera murritzekoak edo gabeak direla. Horretaz gainera, kontuan izan behar da sateliteak diseinatu, eraiki, orbitan jarri eta maneiatzeak kostu oso handiak eragiten dituela. Alderaketa, baina, onura-kostu testuinguru batean eginda, ikusiko dugu tokiko neurketak baina erlazio hobea dugula satelite bidezko behaketen kasuan.

Satelite bidezko behaketa horiek lurra orbitatzen duten sateliteetan helburu horrekin propio jarritako detektagailuen bidez egindako neurketetatik eratorriak dira. Gailuek ez dituzte interesatzen zaizkigun aldagai horiek zuzenean neurtzen, beste aldagai fisiko batzuk baizik, eta horiek eraldatu ostean izango dira eskuragarri intereseko aldagaiak. Lan honetan erabiliko diren aldagaien kasuan espektro elektromagnetikoaren tarte desberdinetako erradiazioren intentsitateak daude jatorrian, infragorrian tenperaturarentzat eta ikusgaian klorofilarentzat. Neurketa horiek eraldatu eta konbinatu egiten dira, itsas gainazaleko tenperatura eta klorofila kontzentrazioa eskuratzeko, gure kasuan.

Satelite bidezko behaketa horiek ozeanoaren lehen geruzari buruzko informazioa ematen digute ia modu esklusiboan, hala nola haren tenperatura, kolorea, itsas gainazalean eragiten duen haizea (zeinak gainazal korronteak edo olatuak ezagutzeko modua ematen baitu). Aldagaien kopurua ez da txikia, eta haziz doa teknologiak garatuz doazen heinean, eta horietako bakoitzak bere ezaugarri propioak ditu, nola estaldura espazialari, bereizmenari edo behaketa maiztasunari dagokienez. Edonola, aurrekaririk gabeko satelite behaketen garai berri honek itsas gainazalean gertatzen diren prozesuen ezagutzan aurrerapauso ikaragarri bat ekarri $\mathrm{du}$, eta oraindik ere bada aurrera egiteko tartea datozen urteetara begira, orbitan jarri berri diren zein datozen urteetan jarriko diren neurketa tresnei esker.

Epe luzeko azterketei dagokienez, hamarkada bat baina gehiagoko luzeraz ari bagara adibidez, orain ez asko arte satelite bidezko behaketak hankamotz geratu dira tokiko behaketekin alderatuz gero. Izan ere, bigarrenen kasuan hamarkada askotako luzera duten denbora serieak eskuragarri dauden arren, oraintsu arte ez da hala izan sateliteko behaketen kasuan. Arazo hori apurka-apurka gaindituz goaz, gaur egun aldagaien arabera ia lau hamarkadako behaketa sistematikoak ere eskuragarri bai- 
taude. Horrek klima aldaketaren seinalea identifikatzeko azterketentzat bereziki interesgarriak egin ditu satelite bidezko behaketak. Izan ere, argudio horri jarraikiz, Europako Espazio Agentziak (ESA) Klima Aldaketako Ekimena (CCI ingelesez) jarri du martxan [1]. Horren xedea azken hamarkadetan satelite bidez egindako aldagai geofisiko eta biologikoen neurketa guztiak aldagaiz aldagai sailkatzea eta klima aldaketa aztertzeko baliagarri izango diren datu base homogeneoak sortzea da, horretarako eskuragarri dauden iturri guztietako satelite behaketak konbinatuaz. Hemen aurkeztutako lanean bi aldagai izango dira aztertuko direnak: itsas gainazaleko tenperatura $\left({ }^{\circ} \mathrm{C}\right)$ eta itsas gainazaleko klorofilaren kontzentrazioa $\left(\mathrm{mg} / \mathrm{m}^{3}\right)$. Itsas gainazaleko satelite bidezko behaketentzat eskuragarri dagoen datu base handiena, Pathfinder [2] izenekoa, erabiliko da, eta itsas gainazaleko klorofila kontzentrazioari dagokionez, berriz, aipatutako CCI datu basea.

Aipatu berri diren epe luzeko azterketa hauetarako, baina, klima aldaketarekin loturik direnak barne, satelite bidezko behaketa gehienek arazo garrantzitsu bat dute: satelite irudietan agertu ohi den zulo kopurua edo datu falta oso handia. Satelitearen eta itsas gainazalaren artean kokaturiko lainoak dira zulo horien erantzule nagusiak. Lainoak espektro elektromagnetikoaren tarte batzuentzat gardenak badira ere (mikro uhinak adibidez), ez da hala izaten aldagai gehienak ondorioztatzeko erabiltzen diren espektroaren tarteentzat (infragorria, ikuskorra...), eta, beraz, lainorik egonez gero satelitea ez da gai itsas gainazalaren propietateen neurketak egiteko, eta, ondorioz, zuloak edo datu faltak izango ditugu satelite irudian honi lotuta. Zulo kopurua txikia den kasuetan, balizko eragina egin nahi den azterketan txikia izatea gerta daiteke, baina ez da hala izaten satelite bidezko behaketa gehienen kasuan zulo portzentajeak oso handiak izaten direlako. Datu horien kasuan, beraz, epe luzeko aldakortasun azterketak egin aurretik zuloen arazoa konpontzeko pauso gehigarriak behar dira. Funtsean sateliteko irudietan zuloak dauden kasuetarako zulo horiek zentzuzko balioekin ordezkatzeko teknika baten beharraz ari gara. Horrelako tekniken artean oso eraginkorra dela frogatu duen bat aplikatuko da lan honetan, DINEOF («Data INterpolating Empirical Orthogonal Functions») izenekoa [3].

Teknika hori aplikatuz zulorik gabeko irudiz osatutako itsas gainazaleko tenperatura eta klorofila kontzentrazioak sortuko dira, lehenik azterketa egiteko eremua kontuan izanda (ikus 1. irudia). Behin zulo gabeko datuak sortu direla, tenperaturaren eta klorofilaren urtaroko zikloak, edo haien urtean zeharreko aldakortasunari loturiko zikloak bestela esanda, identifikatuko dira. Azkenik ziklo horiek denboran zehar aldaketarik jasaten ari ote diren argituko da. 


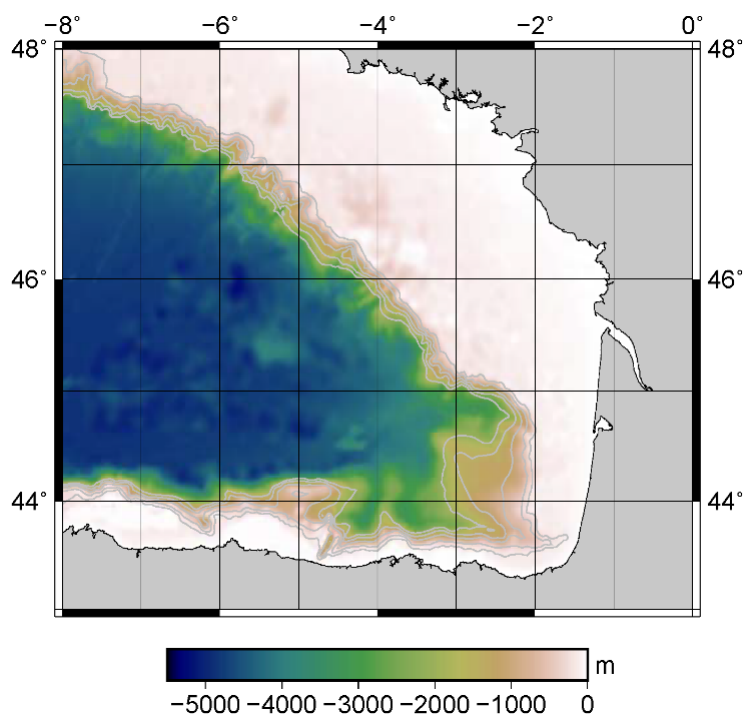

1. irudia. Bizkaiko Golkoaren barnealdeko azterketa eremua eta haren batimetria. Sakonera (m) kolore eskalan, eta $2.000,1.500,1.000,500$ eta $300 \mathrm{~m}$ sakonerako maila kurbak kolore grisez adierazirik.

\section{DATUAK}

Satelite jatorria duten bi datu base erabiliko dira lan honetan. Datu base horiek aldagai jakin baten irudi sorta handi bat besterik ez dira, irudietako bakoitza egun bati dagokiola eta irudiak kronologikoki antolaturik daudela, eta irudietako pixelen patroia (eremu geografikoaren gelaxka bidezko diskretizazioa) komuna izanik denbora ardatz osoan zehar. Irudi horiei dagokien eremua Bizkaiko Golkoko barnealdeko eremua da, 1. irudian ikus daitekeenez. Modu horretan konbinatutako bi datu base horiek itsas gainazaleko tenperatura eta klorofila kontzentrazioei dagozkienak dira. Hona hemen bakoitzaren xehetasunak. 1. irudian ikusten da Bizkaiko Golkoko batimetria (puntuz puntuko ur sakonera) bortitza dela. Izan ere, zenbait tokitan kostatik kilometro gutxira (60-70) sakonera $4000 \mathrm{~m}$ baino handiagoa da.

\subsection{Sateliteko itsas gainazaleko tenperaturaren datuak}

Pathfinder [2] izeneko itsas gainazaleko tenperaturari buruzko datu basea bereizmen espazial altuko ( $4 \mathrm{~km}$ inguru) irudiz osaturik dago, eta 1980ko hamarkadaren hasiera du abiapuntua. Eguneko bi irudi daude es- 
kuragarri, oro har esanda bata egunari eta bestea gauari dagozkienak. Egunean zehar eguzki erradiazioak asko berotzen du itsas gainazaleko lehen geruza mehe bat, sateliteak neurtzen duen tenperatura geruza horrena izanik, eta ez itsas gainazalaren tenperaturaren adierazgarri den magnitude bat. Hortaz, egunean zeharreko irudiekin lan egiteak berezko konplikazio hori dakarrenez, lan honetan gauez soilik neurtutako irudiak erabiliko dira; hau da, eguzki erradiaziorik ez denean behatutako tenperaturak soilik erabiliko dira. Aldagai horren kasuan, ESAko CCI datuak baino beste datu iturri hau, Pathfinder, hobetsi da denbora tarte handiagoa eskaintzen duelako: 1981-2018 tartea 1991-2018 epearekin alderatuz. Hemen erabiliko diren datuen kasuan, 1981-2018 urteen tartea da erabiliko dena, epe horretako egun bakoitzeko irudi bat izanik, eta irudiek hartutako eremua 1. irudian ikus daitekeena izanik.

\subsection{Sateliteko itsas gainazaleko klorofila kontzentrazioari buruzko datuak}

ESAren CCI proiektuan [1] sortutako itsas gainazaleko klorofila kontzentrazioaren $\left(\mathrm{mg} / \mathrm{m}^{3}\right)$ datuak [4] dira lan honetan erabiliko direnak. Klorofila kontzentrazioaren kasuan sateliteak ez du aldagaia zuzenean neurtzen. Horren ordez espektro ikusgaieko banda anitzeko irradiantzia neurtzen da, eta banda desberdinetako balioak algoritmo bidez konbinatzen dira klorofila kontzentrazioa zenbatesteko. Algoritmo horiek tokian bertan hartutako ur laginetan neurtutako klorofila kontzentrazioak eta tarte desberdineko irradiantziak konbinatuz lortuak izan dira aurrez, hori sateliteko instrumentuaren kalibrazioari dagokion pausoa izanik. Erabiliko diren CCItik eskuratutako klorofila kontzentrazioko irudiek ere bereizmen espazial handia dute (4 $\mathrm{km}$ inguru), tenperatura irudiek bezala, eta irudien maiztasuna ere egunerokoa da. Kasu honetan baina eskuragarri den denbora tartea laburragoa da, 1997-2018 urteen artekoa hain zuzen ere.

\section{METODOLOGIAK}

Jarraian datozen bi azpi-ataletako bakoitzean azaltzen dira erabilitako teknika estatistiko nagusiak. Emaitzen atalean eta kalkuluak egiteko orduan jarraitutako ordena kronologikoan emanak datoz azalpenak. Hortaz, lehenik satelite behaketez osatutako datu baseetako zuloak berreraikitzeko erabilitako teknikaren xehetasunak ematen dira. Bigarrenik, zulorik gabeko irudiz osatutako datu baseetatik urtaroen zikloari buruzko informazioa eta horren joerak ondorioztatzeko erabilitako teknikak azaltzen dira. 


\subsection{DINEOF}

Behaketa geofisikoetan zuloak betetzeko arrakastatsu bilakatu den teknika da, jarraian azaltzen denez. Data Interpolating EOF, edo DINEOF [3], osagai nagusi duen teknika bat da, edo EOF bidezko deskonposaketan [5] oinarritutakoa. EOF analisia iteratiboki aplikatzean datza, hasierako datuetan dagoen informazioa baliatuz datuak falta diren lekuetan zuloak betetzeko. Teknikaren funtsa da: jatorrizko datu basearen EOF bidezko deskonposaketa baten bidez horren bertsio berri bat eskuratzea EOF kopuru jakin bat erabiliz. Hori egiten den aldiro jatorrizko datu multzoa apur bat aldatuko da, hasierako zuloak barne. Prozesua behin eta berriz errepika daiteke konbergentzia lortu arte, prozesua aldi berean EOF kopuru desberdinentzat errepikatuaz. EOF kopuru optimoa erabakitzeko balioztatze gurutzatuko pauso bat gehituaz osatzen da teknika.

Aipatu behar da irudien zuloak berreskuragarriak direla baldin eta irudietan informazio minimo bat badago soilik. Beraz, egun batzuetan pixel guztiak galduta badaude edo eskuragarri dagoen pixel kopuru oso txikia bada, irudia berreraikitzea ezinezkoa da. Horri jarraikiz, soilik informazio kopuru minimo bat duten egunak dira berreraikiko direnak.

Teknikari buruzko xehetasun teknikoak [6, 7, 8] erreferentzietan daude, eta, hemen emango ez badira ere, proposatutako aplikazioari dagozkion xehetasunak bai aipatuko dira. Analisia gauzatzeko denbora ardatzean gutxienez datuen $\% 5$ eskuragarri duten irudietako pixelak erabili dira soilik, bai tenperaturan bai klorofilan; aztertutako egunei dagokienez ere, soilik gutxienez datuen \% 5 eskuragarri duten irudiak hartu dira kontuan analisian; klorofilaren kasuan, bere probabilitate banaketako funtzioa gausiarra ez denez aldagaiaren logaritmo hamartarrari aplikatu zaio teknika, aldagaiari berari aplikatu ordez; eta balioztatze gurutzatua (cross-validation [5]) pausorako jatorrizko datuen \% 5 erabili da, datuen aukeraketa modu errealistan eginda $[7,9]$.

\subsection{Analisi harmonikoa eta joerak}

DINEOF teknikaren bidez zuloak bete eta gero, itsas gainazaleko tenperatura eta klorofilako artxiboetan eragiketa bi egin ditugu. Lehenengoan, Bizkaiko Golkoko eguneko batez besteko balioak kalkulatu ditugu. Horretarako, sareko puntuen azalerak latitudearekin duen menpekotasuna kontuan hartu dugu. Ondoren, batez besteko eta pixel banaketako segidetan, jarraian azaltzen den eredu harmonikoa doitu da. Hau da, datuak (bai gainazaleko tenperatura bai klorofila) eredu horren bidez $x_{i}=\operatorname{Acos}\left(\omega t_{i}+\phi\right)+\varepsilon_{i}$ deskribagarriak direla jo dugu. Ekuazio horretan, $x_{i}$ tenperatura edo klorofilaren segidako $i$. elementua da. $A$ urteko zikloaren anplitudea da; $\omega=2 \pi / T_{t}$, urte tropikalaren bidez ( $T_{t}=365,2419$ egun) definituriko maiztasun angeluarra; $\phi$, urteko zikloaren fasea, eta $\varepsilon_{i}$, sistemako prozesu estokastikoen ondorioz ager- 
tzen den osagai estokastikoa. Doiketa harmonikoa ez ezik, literaturan beste tresna batzuk ere erabiliak izan dira; demodulazio konplexua, esaterako [10]. Hala ere, kasu honetan, berreraiki ezin daitezkeen egunak existitzen direnez, eguneko laginketa-maiztasuna konstantea ez denez, demodulazio konplexua ezin da erabili, eta horregatik analisi harmonikora jo dugu [11]. Anplitudea eta faseak urte batetik bestera aldakorrak diren ala ez jakiteko, doiketa harmonikoa 3 urteko segmentuen lehiatila mugikorra aplikatuz kalkulatu da. Beraz, irudietan aurkeztutako anplitudea eta faseak urtearen funtzioak dira, eta hiru urteko segmentuetako erdiko urtean kokatu dira tenporalki. Anplitude eta faseetan egon daitezkeen ziurgabetasunak zehazteko, «bootstrap» metodoa erabili da [5], zorizko 2.000 errealizazio sortuz jatorrizko datuetatik kasu bakoitzean, eta 2.000 kasu horietatik \% 95eko konfiantza tarteak kalkulatuz. Doiketa prozesu horretan, anplitudea eta faseaz gainera, jatorrizko datuetan azaldutako bariantza ere kalkulatu dugu. Horrek aukera emango digu ikusteko ea aldagaiak eredu sinple honen arabera ondo azaldu daitezkeen ala ez.

Klorofilaren kasuan agertutako bariantzaren frakzioa txikia denez, urtaroen zikloa ez-harmonikoa delako, beste modu bat bilatu dugu urtaroen zikloa definitzeko. Harmonikoak ere doi litezke, baina, parametroen kopurua (osagai harmoniko bakoitzeko beste bi parametro doitu behar dira, eta zikloa oso irregularra da) txikia mantentzeko, urtaroen ziklo egonkorrak beste modu batera definitu ditugu. Egun bakoitzean, urtarrilaren 1etik pasatutako egunen kopurua kalkulatzen da. Egun kopuru horretan nahasi egin dira urte guztietako egun bereko klorofila-datuak zerrenda batean, bai pixel bakoitzean bai Bizkaiko Golkoko batezbestekoan. Ondoren, egun horretako banaketatik klorofila-kontzentrazioaren mediana aukeratu da, zikloa ahula izanik aldakortasuna handia baita multzo horretan, batezbestekoan eragin handia luketen mugako balioak barne. Eragiketa hori egun guztietan errepikatuz, klorofilaren ohiko portaera ziklikoa identifikatu da. Hala ere, datuetan irregulartasuna oso handia denez, azken eragiketa moduan, maiztasun baxuko osagaiei pasatzen uzten dien Kolmogorov-Zurbenko iragazkia pasatu da lortutako klorofilako medianetatik [12], urteko zikloa leunduz. Leundutako zikloa klorofilaren urtaro-ziklotzat hartu da, harmonikoa ez bada ere.

Aldagaien denbora joerak kalkulatzeko Sen metodoa erabili da. Erregresio lineal bidez kalkulatutako maldekin alderatuz, Sen bidez lortutako joerak estatistikoki sendoagoak dira $[13,14]$. X eta Y bektore bi izanik, Sen metodoak zoriz $(\mathrm{x}, \mathrm{y})$ bikote bi aukeratzen ditu, eta, erregresio lineala erabiliz, bien arteko malda kalkulatzen du.

Prozesu hori hainbat bider errepikatu da (ehunka batzuk), aldi bakoitzean $(\mathrm{x}, \mathrm{y})$ bikote ezberdinak zoriz aukeratuz eta, ondorioz, malda ezberdin bat lortuz ziklo bakoitzean. Hainbat malda kalkulatu ondoren, joera-banaketa lortu da, eta hortik \% 95eko konfiantza-tarteak erraz atera daitezke. Joera nagusia, malda guztien mediana da, eta, \% 95eko konfidantza-tartea- 
ren barnean 0 balioa ez baldin badago, medianak ematen duen joera esanguratsua izango da. Aldiz, 0 balioa tartearen barruan badago, medianak emandako joera ez da esanguratsua izango.

\section{DATUEN AZTERKETA}

Lehenik eta behin datu baseetako zuloak betetzeko DINEOF teknikaren aplikazioari dagozkion emaitzak datoz atal honetan, eta tenperaturaren eta klorofilaren datuak batera aztertzen dira. Jarraian modu bereizian azaltzen dira itsas gainazaleko tenperaturaren eta klorofilaren urtaroen zikloa, eta horien joerei dagozkien azterketak (aurrerago, emaitzek bereizketa hori argi justifikatuko dute).

\subsection{Itsas gainazaleko tenperaturaren eta klorofilaren berreraikuntza}

DINEOF teknikaren azalpenean adierazi bezala, datuen $\% 5$ eskuragarri duten egunak hartuko dira kontuan, eta horiekin batera datuen $\% 5$ eskuragarri duten pixelak ere bai. Tenperaturaren eta klorofilaren datuei baldintza horiek aplikatu ondoren, 1. taulan ematen dira berreraikuntza aplikatuko zaien datu baseen propietateak aztertutako bi aldagaientzat.

1. taula. Itsas gainazaleko tenperaturaren $\left({ }^{\circ} \mathrm{C}\right)$ eta klorofilaren $\left(\mathrm{mg} / \mathrm{m}^{3}\right)$ berreraikuntzei dagozkien xehetasunak. Bigarren zutabean, aztertutako epea. Hirugarrenean, epe horretako egun kopurua parentesi artean eta aztertutako egun kopurua aurretik. Laugarrenean, bi aldagaien irudietako pixel kopurua eta pixel kopuru osoa, lurra eta alde batera utzitako puntuak barne, parentesi artean. Bosgarren zutabean, aldagai bakoitzari dagokion zulo portzentajea. Azken zutabean aldagaiaren berreraikuntzari dagokion errorea, aldagaiaren unitatetan emana.

\begin{tabular}{l|c|c|c|c|c}
\hline \multicolumn{1}{c|}{ Aldagaia } & Epea & Irudiak & Pixelak & Zuloa (\%) & Cv-Rmse \\
\hline $\begin{array}{l}\text { Itsas gainaza- } \\
\text { leko tenperatura }\end{array}$ & $\begin{array}{c}1981-08-24 / \\
2018-09-30\end{array}$ & $7696(13552)$ & $15832(23040)$ & 73,5 & $0,46 \mathrm{~K}$ \\
\hline $\begin{array}{l}\text { Itsas gainaza- } \\
\text { leko klorofila }\end{array}$ & $\begin{array}{c}1997-09-16 / \\
2018-12-31\end{array}$ & $3978(7777)$ & $16244(23040)$ & 64,3 & $0,19 \mathrm{mg} \cdot \mathrm{mg} / \mathrm{m}^{3}$ \\
\hline
\end{tabular}

1. taulako hirugarren zutabeak adierazten digun bezala, orotara berreraiki den egun kopurua, aztertutako aldagaiaren arabera, \% 50-60 tartean dago, eta apur bat altuagoa da tenperaturaren kasuan. Taula berean ikus daitekeenez, zuloa edo faltan den datu portzentajea oso altua da bi kasuetan (ia \% 74 tenperaturaren kasuan). Taula horretako azken zutabeak berreraikuntza bakoitzari esleitutako balioztatze gurutzatuz kalkulatutako 
errore-estimazio bat emango digu, bi kasuetan hemen egin nahi dugun aplikaziorako errorea tarte onargarrian dagoela.

2. irudiak DINEOF bidezko berreraikuntzen bigarren ikuspuntu bat emango digu. 2018ko irailaren 16ari dagozkion itsas gainazaleko tenperaturaren eta klorofilaren irudiak ikus ditzakegu hurrenez hurren lehenengo zutabean (a eta c). Ikus daitekeenez, oso nabaria da zuloen kopuru handia (pixel zuriak). Bigarren zutabean, berriz, (b eta d) egun bereko irudiak erakutsi dira DINEOF berreraikuntza teknika aplikatu ostean. Jatorrizko irudian datuak ziren puntuetan diferentzia txiki batzuk ikus badaitezke ere, 1. taulak adierazitako magnitude ordenakoak, zulorik gabeko irudiak oro har bat datoz jatorriko datuekin.

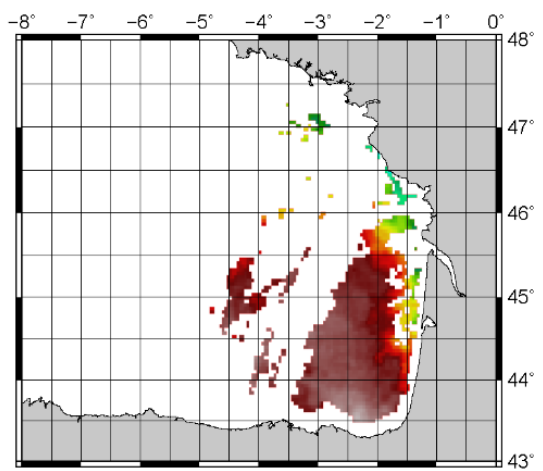

a)

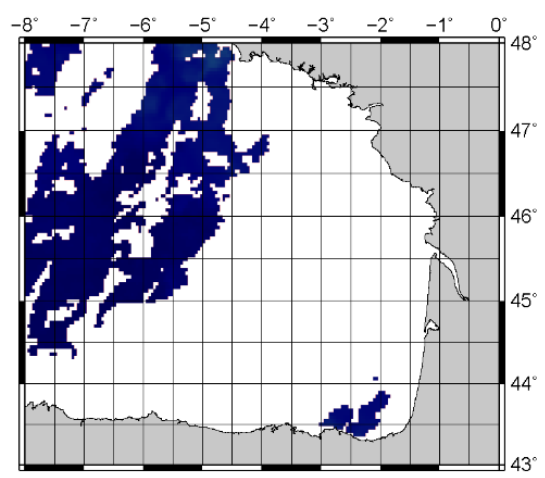

c)

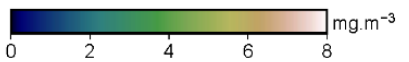

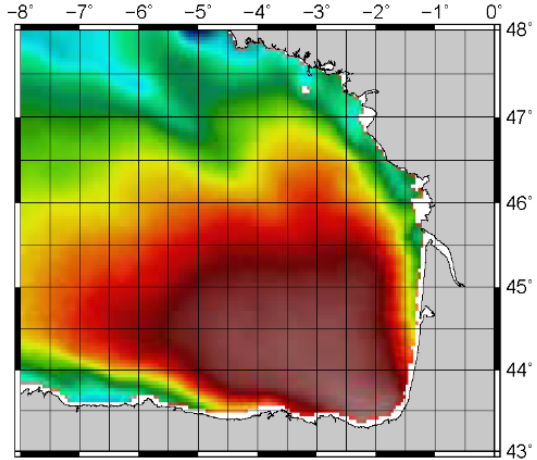

b)
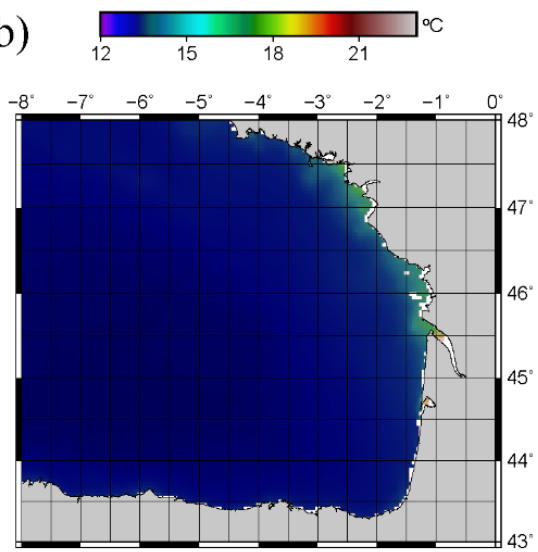

d)

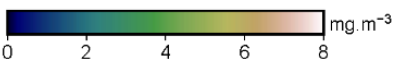

2. irudia. DINEOF berreraikuntza teknikaren aplikazioaren adibidea. Itsas gainazaleko tenperatura lehen lerroan $(a, b)$, eta itsas gainazaleko klorofila kontzentrazioa bigarrenean $(\mathrm{c}, \mathrm{d})$. Lehen zutabean $(\mathrm{a}, \mathrm{c})$, jatorrizko satelite irudia lainoek eragindako zuloekin (pixel zuriak). Bigarren zutabean $(b, d)$, teknika aplikatu ostean irudia berreraikirik. 


\subsection{Itsas gainazaleko tenperatura: urtaroen zikloa eta joerak}

Aurreko atalean berreraikitako tenperatura datuen azterketa egingo da. Lehenik, datu horietan urtaroen zikloak duen itxuraz eta adierazgarritasunaz arituko gara, jarraian ziklo hori denboran aldatzen ari ote den, eta nola, aztertzeko.

3. irudian (a), aztertutako eremuan zehar puntuz puntu urtaroen zikloak azaldutako bariantzaren portzentajea azaltzen digu. Metodologian azaldu bezala puntu bakoitzeko epe osorako seinalea harmoniko sinple baten bidez egokitzen da. Irudi horrek adierazten du seinale harmoniko hutsaren bariantzak jatorrizko seinalearen bariantzaren zein portzentajea azaltzen duen. Ikus daitekeenez, eremuko puntu guztietan portzentaje hori oso altua da (\% 90 edo altuagoa leku gehienetan), eta, beraz, ikus daiteke tenperaturaren aldakortasunaren zati oso handi bat urtaroen zikloari lotua dela. Horretaz gainera, 3. irudiak (b) portzentaje horren eboluzioa ere ematen digu, oraingoan eremua bere osotasunean harturik. Kasu honetan, seinaleen harmonikoaren doitzea, epe osoa (4 hamarkada) kontuan izan ordez, 3 urteko tartetan aztertu da. Ikus daitekeenez, urtez urteko eboluzioan urtaroen zikloa beti da aldakortasunaren eragile nagusia (bariantzaren portzentajea \% 90 inguruan edo gainetik da gehienetan), nahiz eta beste prozesu eta seinale batzuek duten eragina ere hor izan. Emaitza horrek adierazi du itsas gainazaleko tenperaturaren seinalean urtaroen zikloa dela aktore nagusia; eta jokamolde hori denboran jarraitua denez, zikloan jasandako balizko aldaketek izango dutela zeresana tenperaturaren epe luzeko aldaketei erreparatzen diegunean. Hori behin argiturik, orain urtaroen zikloa ezaugarritzen duten bi aldagaiak aztertuko dira: zikloaren anplitudea eta fasea, hurrenez hurren.
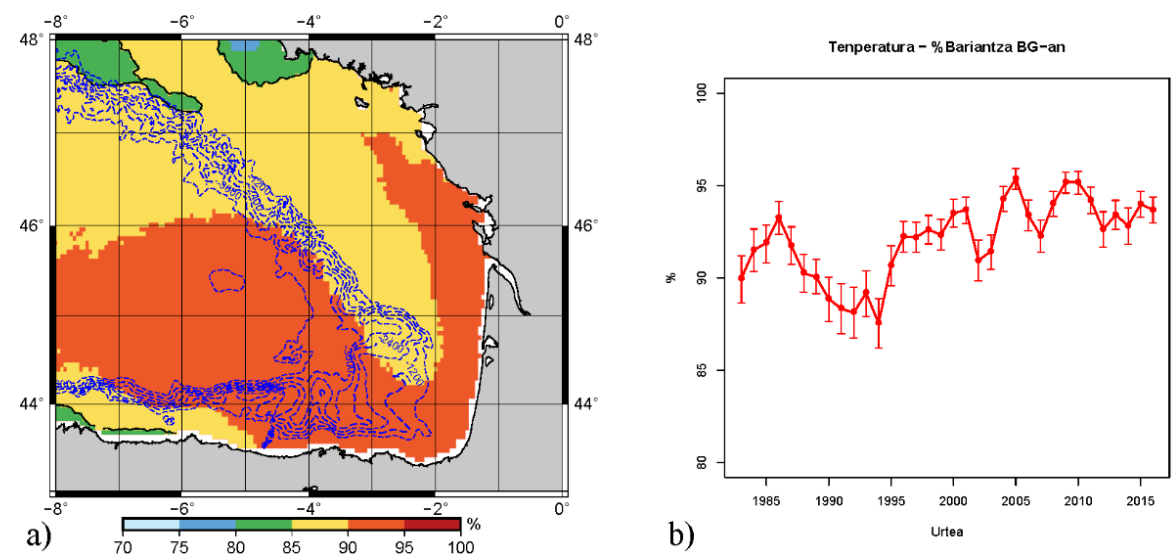

3. irudia. Itsas gainazaleko tenperaturan urtaroen zikloaren bariantzak bariantza osotik azaldutako portzentajea posizioaren arabera (a). Eremu osoaren bariantza portzentajearen eboluzioa denbora ardatzean hiru urteko bloketan ondorioztatua (b). 
4. irudian, itsas gainazalaeko tenperaturari analisi harmonikoa eremuan zehar puntuz puntu aplikatu ostean lortutako anplitude (K) eta fase (egun) mapak ematen dira (a eta b). Irudiak erakusten digu Bizkaiko Golkoaren ekialderantz zikloaren anplitudea handiagoa dela, hau da, urteko zikloko tenperatura maximo eta minimoen arteko tartea handiagoa dela. Ez dirudi patroi espazial horrek inguruneko batimetriarekin (marra eten urdinak) lotura esturik duenik. Faseari dagokionez, zikloaren maximo edo minimoa gertatzen den urtearen egun erlatiboa adieraziko ligukeena puntu desberdinak alderatzean, ikusten dena da zenbat eta ekialderago orduan eta geroago gertatzen dela. Kasu honetan, eta Frantziako plataforma kontinentalari dagokionez bereziki, batimetriaren eragina ikus daiteke, fasearen eta batimetriaren maila lerroak paralelo baitira hor.
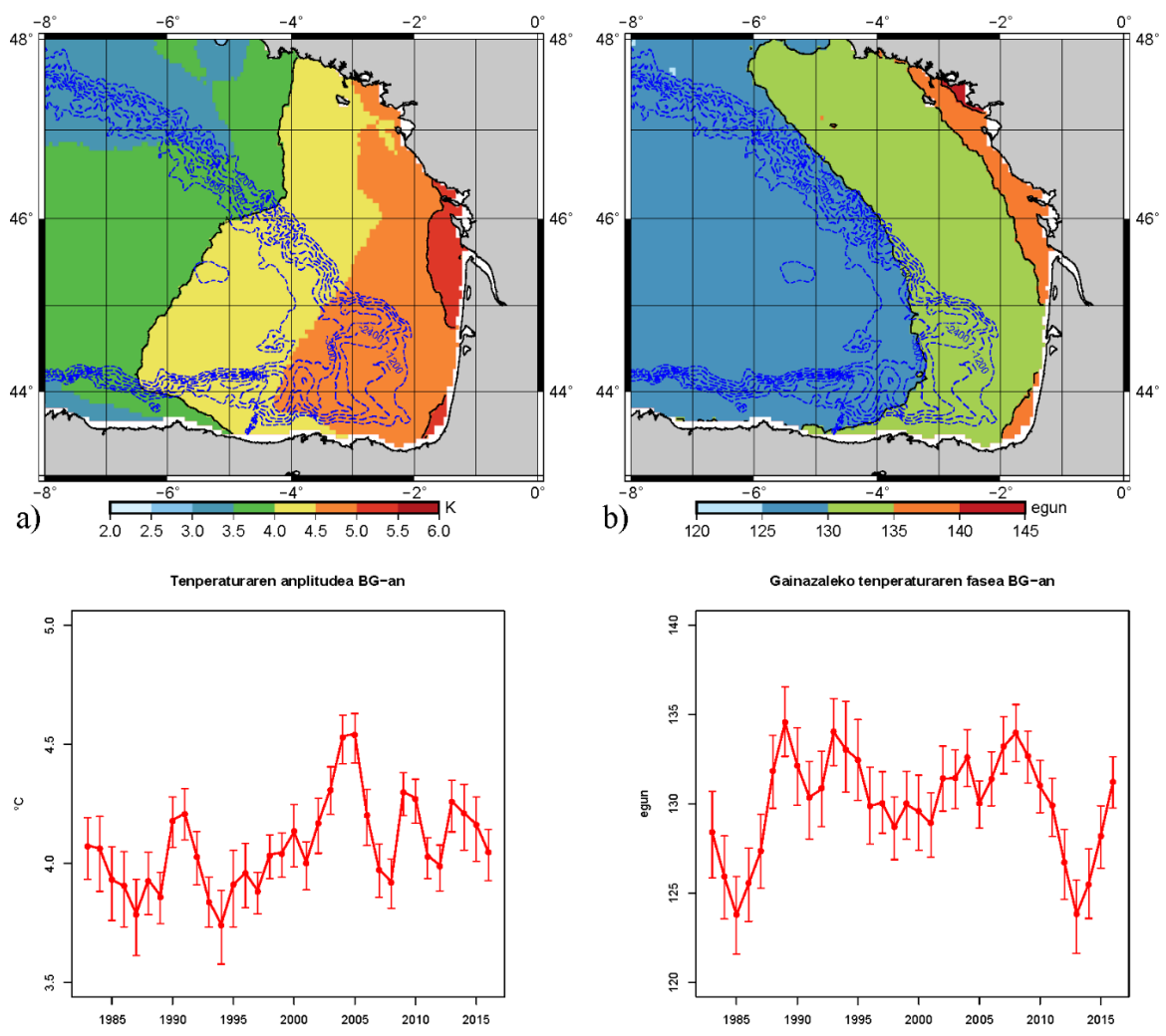

c)

Urtea

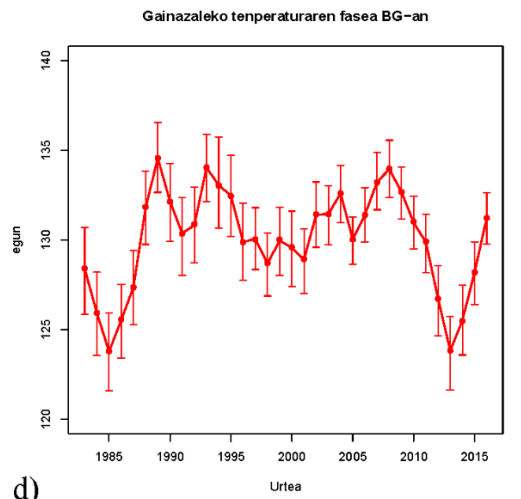

4. irudia. Itsas gainazaleko tenperaturaren urtaroen ziklo harmonikoaren anplitudea (a) eta fasea (b) eremuan zehar. Eremua osotasunean harturik anplitudearen (c) eta fasearen (d) denbora eboluzioa 3 urteko bloketan ondorioztatua. 
Anplitude eta fase horiek, baina, esku artean dugun denbora tarte osoa aztertzean eskuratu ditugunak dira, baina metodologian azaldu gisan, 3 urteko tarteak erabiliz ere errepikatu da azterketa, kasu horretan eremua bere osotasunean hartuz. 4. irudiaren bigarren lerroan (c eta d) daude ikusgai horrela lortutako urtez urteko anplitudearen eta fasearen eboluzioak. Horiekin batera bootstrap bidez lortutako urtez urteko balioen ziurtasun tarteak ere ematen dira (ikus 3.2 atala metodologian). Tenperaturaren anplitudearen eboluzio kurban ikus genezake oro har anplitude hori $4{ }^{\circ} \mathrm{C}$ bueltan dabilela. Eboluzio horren denboran zeharreko bilakaera datozen lerroetan aztertuko da. Faseari dagokionez, ikus genezake batez beste 130 egunen bueltan dabilela (tenperatura minimoa, beraz, urtea hasi eta 40-50 egunera). Edonola balio horren azpitik ere astebete bueltan jaisten diren balioak baditugu, urtaroak aurreratzen direlarik, beraz, kasu horietan, baina kontrakoa ere gertatzen den kasuak ere hor daude. Denboran zeharreko eboluzio horren joerak jarraian aztertzen dira.

2. taulan, Sen metodoa erabiliz, anplitudea, fasea eta urtaroen zikloari lotutako bariantza portzentajearen joerak ikus daitezke (Bizkaiko Golko osoko segidetan). Taulan adierazten den gisa, tenperaturaren anplitudean zein bariantza frakzioaren kasuan joera adierazgarriak ondorioztatzen dira. Joera biak positiboak direnez, emaitza horrek adierazten duena da urtaroen zikloaren anplitudeak handitzeko joera adierazgarria duela, hau da, maximoaren eta minimoaren arteko tartea handiagotzen ari dela. Bigarrenik bariantza portzentajearen joera adierazgarriak esaten duena da aldakortasun osoaren gero eta proportzio handiagoa dagoela urtaroen zikloari loturik.

2. taula. Itsas gainazaleko tenperaturaren urtaroen zikloaren anplitudearen, fasearen eta urtaroen zikloak azaldutako bariantza portzentajearen joerak Bizkaiko Golkoan. Joerak eta horien konfiantza tarteak adierazi dira taulan.

\begin{tabular}{lcc}
\hline & Joera & $\%$ 95eko konfiantza tartea \\
\hline Anplitudea & $0,11\left[{ }^{\circ} \mathrm{C} /\right.$ hamarkada $]$ & {$[0,07 ; 0,13]$} \\
Fasea & Joerarik ez & ------------ \\
Bariantza $(\%)$ & $1,55[\% /$ hamarkada $]$ & {$[1,23 ; 1,81]$} \\
\hline
\end{tabular}

\subsection{Klorofila kontzentrazioa: urtaroen zikloa eta joerak}

5. irudiak (a) aztertutako eremuan eta klorofilaren kasuan urtaroen zikloak azaldutako bariantza frakzioa adierazten du. Itsas gainazaleko tenperaturarekin alderaturik, lehen ikusten dena zera da: klorofilaren kasuan zikloaren portzentajea askoz txikiagoa dela. Kasu honetan ere ikusten da badela erlazioa batimetriarekin. Eremuaren hego-mendebaldeko gunean, $\% 40$ bueltan bada ere, balioak oro har horren azpitik egoten dira, bere- 
ziki Frantziako plataforma kontinentalaren gainean. Kasu horretan argia da jokamolde horren eragilea: Frantziako plataforma kontinentalean urak isurtzen dituzten ibai handien eraginak dakar emaitza hori, bariantza portzentaje txikienak diren kokaguneetan isurtzen baitute guneko ibai horiek. Isurketa horiek eragin zuzena dute itsas zabalean ondoren garatuko diren klorofila kontzentrazioetan, baina isurketen izaerarengatik beragatik urtez urteko ziklo errepikakor batekin bateragarri ez den eboluzio patroi bat garatzen da fenomeno horri jarraikiz. Kontrara, ibai uren emaria izateagatik eragina txikiagoa den gunetan, Penintsularen iparrera sakonera handitzen den gunean, zikloaren garrantzia nabariagoa da.
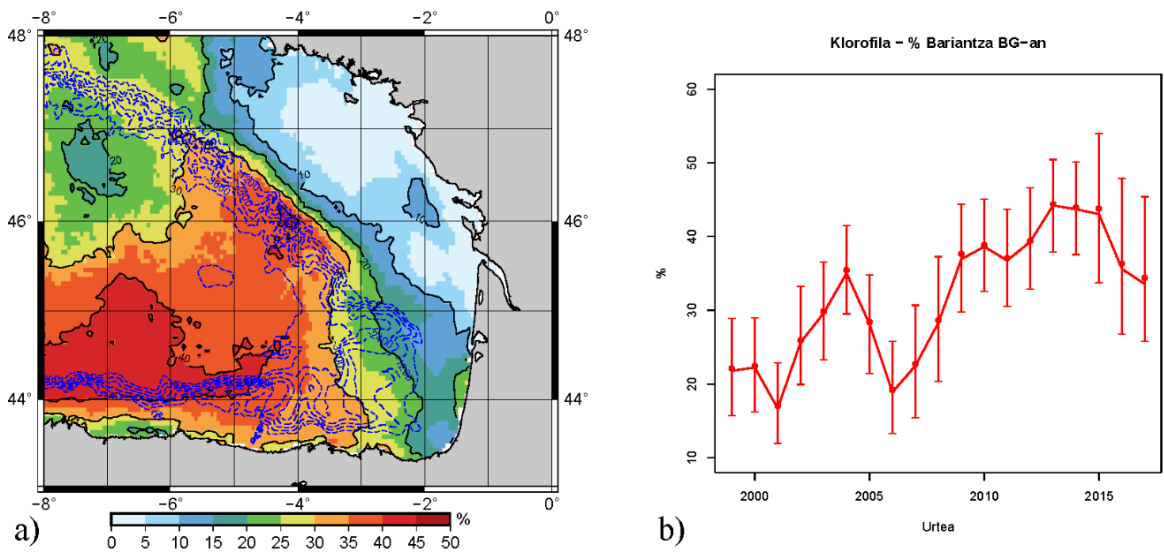

5. irudia. Itsas gainazaleko klorofila kontzentrazioan urtaroen zikloaren bariantzak bariantza osotik azaldutako portzentajea posizioaren arabera (a). Eremu osoaren bariantza portzentajearen eboluzioa denbora ardatzean hiru urteko bloketan ondorioztatua (b).

Metodologian adierazi den moduan urtaroen zikloa bera definitzea ere zaila egiten da klorofilaren kasuan, eta datuak leundu eta guzti ere, geratzen den zikloa ez da oro har seinalearen eragile nagusia izaten. Urtaroen zikloak azaldutako bariantza portzentajearen denbora eboluzioari dagokionez, berriz, 5. irudiak (b) aldakortasun nabaria erakusten du urte jakin batzuetan balio txikienen ia balio bikoitzak eskuratuaz. Edozein kasutan, portzentajeak ez dira inoiz tenperaturaren balioekin alderagarriak.

Jarraian, tenperaturaren kasuan egindakoa errepikatzeko, urtaroen zikloaren anplitude eta fase mapak aztertzea litzateke hurrengo pausoa. Hala ere, 5. irudiaren azterketan esan berri denez, urtaroen zikloa ez da oro har aldakortasun modu indartsu bat eremuaren gune gehienetan, eta hori dela eta ez dira irudi horiek hemen emango. Klorofilaren urtaroen zikloaren anplitude eta fasearen denbora eboluzioaren joerak ere interesgarri lirateke, 
aurreko aldagaiaren kasuan bezala, zikloak azaldutako bariantza portzentajearenak. Hiru horien joerak, baina, tenperaturaren kasuan ez bezala, ez dira adierazgarriak hiru aldagaietako baten kasuan ere.

\section{EZTABAIDA ETA ONDORIOAK}

Gure aurreko lanetan [15] ondorioztatu genuen itsas gainazaleko tenperaturaren berotzeko joera Bizkaiko Golkoan, bai tokiko behaketak erabiliz, bai sateliteko irudiak erabiliz. Itsas gainazaleko tenperaturari dagokionez, lan horiek tokian egindako neurketetan $0,22-0,47^{\circ} \mathrm{C} /$ hamarkadako balioak ematen dituzte, kontuan hartutako hamarkaden arabera (balio handienak azken hamarkadei dagozkie). Gainera, berotze-efektu hori ez da gainazalera mugatzen, eta nabaria da $250 \mathrm{~m}$-ko sakoneraraino (balioak txikituz doaz sakonera handitu ahala). Sateliteko irudietatik eratorritako itsas gainazaleko tenperaturari dagokionez, berriz, patroi espazial ez-homogeneo bat ikusten bada ere gainazaleko tenperaturaren joerarako, hura positiboa da eremu osoan, eta euskal kostaldean $0,30{ }^{\circ} \mathrm{C} /$ hamarkadako balioak hartzen ditu.

Tenperaturaren joerak ikusten denez sendoak dira, eta ongi zehazturik daude, baina tenperaturaren joera horien eta urtaroen zikloaren arteko erlazioa zehazteke zegoen oraindik. Urtaroen ziklo hori, seinale harmoniko baten bidez adierazia, anplitude eta fase baten bidez ezaugarritzen da. Tenperaturaren joera bataz bestearen handitzean ezaugarritu daiteke, zikloaren anplitudean eta fasean inolako eraginik izan gabe. Hemen kasu hori ez dela erakutsi digute emaitzek. Horrela, zikloaren anplitudea handiagotzeko joera adierazgarri bat dela ikusi da; ez, ordea, faseari dagokionez. Anplitudearen joera hazkorrari jarraikiz, emaitza honek adierazten diguna zera da: urtaroen zikloko tenperatura maximo eta minimoen arteko aldea apurka handiagotuz doala. Emaitza horrek, tenperaturaren joera gorakorrarekin batera, adierazten du seguruenik tenperatura maximoen alderditik letorkeela eragina. Puntu hori, hala ere, etorkizuneko lanek argitu beharko dute. Horretaz gainera, emaitzek erakusten dute seinale orokorrarekiko urtaroen zikloa garrantzia irabazten ari dela, zeren, 2. taulan adierazi bezala, urtaroen zikloak azaldutako bariantza portzentajeak joera gorakor adierazgarria baitu.

Fasean detektatutako joera batek urtaroen hasiera/bukaera daten aldaketa bat adieraziko luke. Hemen egindako azterketak erakusten du fase horretan badela aldakortasunik, baina, estatistikoki sendoak diren teknikak erabiliaz joerak ondorioztatzeko, ez da joerarik detektatu. Atmosferan Bizkaiko Golkoko eremuan urtaroen faseen aldaketa adierazgarriak badirela erakusten dute Espainiako Meteorologia Agentziako behaketek eta azken txostenek [16, 17]. Lehen hurbilketa batean itsas gainazaleko tenperaturan ere isla izan beharko luke aldaketa horrek, baina ikusteko dago joera hori 
itsas gainazaleko tenperaturan ere etorkizunean detektatuko den datozen urte eta hamarkadetan.

Itsas gainazaleko tenperaturaz gainera, aldagai biologiko baten eboluzioa ere aztertu da, itsas gainazaleko klorofila kontzentrazioa, horren urtaroen zikloa aldaketarik jasaten ari den argitzeko asmoarekin. Aldagai horrekin lan egitean urtaroen zikloa definitzeko zailtasuna izan da lehenengo oztopoa (ikus metodologia); izan ere zikloa, egotekotan ere, ez da harmonikoa. Edonola ere, eta zikloa definitzeko lana hartuta ere, klorofila seinalearen aldakortasunaren zati ez oso handi bat azaltzen du ziklo horrek. Gainera, haren garrantzia erlatiboa denboran zehar aldatzen bada ere, txiki mantentzen da aztertutako epe osoan tenperaturarekin alderatuz. Emaitza horrek eraman gaitu zikloaren anplitude eta fasea hemen ez lantzera, alde batetik ez direlako klorofilaren bilakaeraren oso adierazgarri eta bestetik ez delako horietan joera adierazgarririk detektatu. Klorofilaren kasuan, beraz, aldaketarako joerak egoterik baztertzen ez den arren lan honetan, urtaroen zikloaren aldaketatik at, joeren azterketa beste eremu batzuetara mugatzea komeni dela ondorioztatzen da.

\section{ESKER ONAK}

Eskerrak ematen dizkiogu Euskal Herriko Unibertsitateari (UPV/EHU) lan hau garatzeko emandako laguntzagatik (GIU17/02).

\section{BIBLIOGRAFIA}

[1] PLUMMER, S., LECOMTE, P., \& DOHERTY, M. (2017). The ESA Climate Change Initiative (CCI): A European contribution to the generation of the Global Climate Observing System. Remote Sensing of Environment.

[2] CASEY, K.S., T.B. BRANDON, P. CORNILLON, and R. EVANS (2010). «The Past, Present and Future of the AVHRR Pathfinder SST Program», in Oceanography from Space: Revisited, eds. V. BARALE, J.F.R. GOWER, and L. ALBEROTANZA, Springer.

[3] BECKERS, J.M., RIXEN, M. (2003), EOF calculations and data filling from incomplete oceanographic datasets. J. of Atmospheric and Oceanic Technology, 12:1839-1856, DOI: 10.1175/1520-0426(2003)020<1839:ECADFF>2.0.CO;2.

[4] BELO COUTO, A., BROTAS, V., MÉLIN, F., GROOM, S., \& SATHYENDRANATH, S. (2016). Inter-comparison of OC-CCI chlorophyll- $a$ estimates with precursor data sets. International Journal of Remote Sensing, 37(18), 4337-4355.

[5] WILKS, D.S. (2006), Statistical Methods in the Atmospheric Science. Academic Press, International Geophysics Series (59). 
[6] ALVERA-AZCARATE, A., BARTH, A., RIXEN, M. and BECKERS, J.M. (2005), Reconstruction of incomplete oceanographic data sets using empirical orthogonal functions: application to the Adriatic Sea surface temperature. Ocean Modelling, 2:325-346.

[7] ALVERA-AZCARATE, A., BARTH, A., BECKERS, J.M. and WEISBERG, R.H. (2007), Multivariate reconstruction of missing data in sea surface temperature, chlorophyll, and wind satellite fields. J. of Geophysical Research-Oceans, 112.

[8] ALVERA-AZCARATE, A., BARTH, A., SIRJACOBS, D. and BECKERS, J.M. (2009), Enhancing temporal correlations in EOF expansions for the reconstruction of missing data using DINEOF. Ocean Science, 4:1812-0784.

[9] ESNAOLA, G., J. SÁENZ, E. ZORITA, A. FONTÁN, V. VALENCIA, P. LAZURE, 2013. Daily scale wintertime sea surface temperature and IPCNavidad variability in the southern Bay of Biscay from 1981 to 2010. Ocean Science, 5(2): 115-139.

[10] D. THOMSON (1995) The seasons, global temperature and precession, Science 268:59-68, DOI: 10.1126/science.268.5207.59

[11] A.R. STINE and P. HUYBERS (2012) Changes in the Seasonal Cycle of Temperature and Atmospheric Circulation. J. Climate, 25, 7362-7380.

[12] W. YANG and I. ZURBENKO (2010), Kolmogorov-Zurbenko filters. WIREs Comp Stat, 2: 340-351. doi:10.1002/wics.71

[13] HIPEL, K.W. and MCLEOD, A.I. (1994),Time Series Modelling of Water Resources and Environmen-tal Systems. New York: Elsevier Science.

[14] SEN, P.K. (1968), Estimates of the regression coefficient based on Kendall's tau,Journal of the American Statistical Association, 63, 1379-1389.

[15] ESNAOLA, G. (2012), Azken hamarkadetako itsas tenperaturaren joerak Bizkaiko Golkoan, EKAIA, ale berezia.

[16] AEMET - Espainiako Meteorologia Agentziaren behaketak: https://opendata. aemet.es/centrodedescargas/inicio

[17] AEMET - Espainiako Meteorologia Agentziaren laburpena: http://www. aemet.es/en/noticias/2019/03/Efectos_del_cambio_climatico_en_espanha 